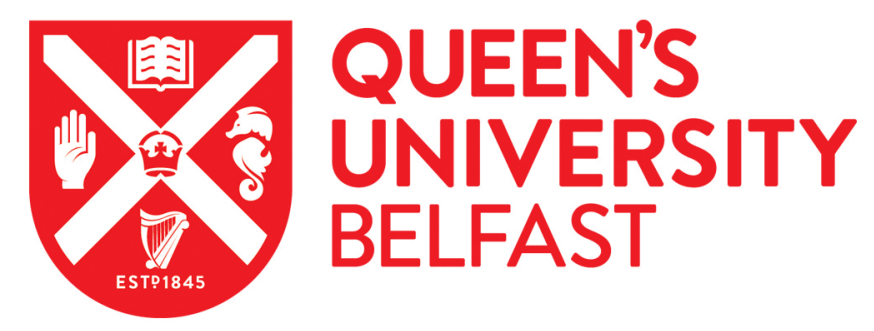

\title{
War, peace and suicide: The case of Northern Ireland
}

Tomlinson, M. (2012). War, peace and suicide: The case of Northern Ireland. International Sociology, 27(4), 464-482. https://doi.org/10.1177/0268580912443579

Published in:

International Sociology

Document Version:

Peer reviewed version

Queen's University Belfast - Research Portal:

Link to publication record in Queen's University Belfast Research Portal

Publisher rights

(c) The Author(s) 2012. This work is made available online in accordance with the publisher's policies. Please refer to any applicable terms of use of the publisher.

\section{General rights}

Copyright for the publications made accessible via the Queen's University Belfast Research Portal is retained by the author(s) and / or other copyright owners and it is a condition of accessing these publications that users recognise and abide by the legal requirements associated with these rights.

Take down policy

The Research Portal is Queen's institutional repository that provides access to Queen's research output. Every effort has been made to ensure that content in the Research Portal does not infringe any person's rights, or applicable UK laws. If you discover content in the Research Portal that you believe breaches copyright or violates any law, please contact openaccess@qub.ac.uk. 


\section{War, peace and suicide: the case of Northern Ireland}

abstract: Durkheim's idea that war reduces suicide through greater social and political integration has been used to explain suicide trends during the Northern Ireland conflict and in the period of peace. The applicability of Durkheim is critically evaluated through a case study of suicide trends by age, gender and cause of death over a forty-year period. The key finding is that the cohort of children and young people who grew up in the worst years of violence during the 1970s, have the highest and most rapidly increasing suicide rates, and account for the steep upward trend in suicide following the 1998 Agreement. Contrary to Durkheim, the recent rise in suicide involves a complex of social and psychological factors. These include the growth in social isolation, poor mental health arising from the experience of conflict, and the greater political stability of the past decade. The transition to peace means that externalised aggression is no longer socially approved. It becomes internalised instead.

keywords: Durkheim • war • suicide $\bullet$ Northern Ireland conflict $\bullet$ peace $\bullet$ gender

\section{Introduction}

In June 1998, the British Medical Journal published a news item with the headline, 'Male suicide rate rises as Irish Troubles ease' (Payne, 1998: 1850). This was a few months after the 1998 Agreement between the Irish and British Governments and all the Northern Ireland political parties. ${ }^{1}$ Violent conflict in Northern Ireland had cost 3,500 lives over a thirty-year period in a region containing barely 1.5 million people. According to one medical source, the conflict had 'protected society' because people had involved themselves in community and public life. With the coming of peace the suicide rate has almost doubled. 
In this brief item, the echoes of Durkheim (2002) are evident, but not surprising, as his work has had an enduring influence on the understanding of suicide for more than a century (Van Poppel and Day, 1996: 500). In essence, Durkheim argued that wars 'rouse collective sentiments, stimulate partisan spirit and patriotism, political and national faith, alike, and (...) cause a stronger integration of society' (2002: 166). Once violence ceases, there is a 'vacuum' and suicide increases as the protective effects of war subside. The notion that a peace process might also generate a greater sense of political integration, especially in societies riven with violent conflict over many years, is apparently not relevant to the observations available to Durkheim at the time. Peace simply meant a return to 'normal' pre-war levels of 'egoistic' and 'anomic' suicides, the two main types of suicide characteristic in 'our great modern States' (Durkheim, 2002: $341)^{2}$

The status of the Northern Ireland conflict is much debated - the contending representations include civil war, national liberation struggle, religious/sectarian conflict, and a problem of terrorism. While this opens up interesting questions about the types of individual and collective political motivation involved, the form of conflict is less important than the similarity of forces generated by in-country political upheaval and war: 'Great national wars have the same effect as political disturbances' - suicides decline (Durkheim, 2002: 205). In all types of conflict, social integration is increased because group members come together to defend collective interests against the threat of outsiders (O’Malley, 1975: 348).

Durkheim was essentially concerned to demonstrate how social factors determine individual consciousness and behaviour. It was crucial to the project of scientific sociology to analyse the phenomenon of suicide - conventionally understood as 'internal, pathological and medical' (Marsh, 2010: 100-114) - and to demonstrate that suicide rates vary between countries and social groups because of differences in social 
forces (Bailey, 1998: 16-18).

Durkheim viewed war as part of political life which, along with religion and family life, comprised the three domains explored in his treatment of social integration and regulation. All three were crucial to the propensities to 'internalised violence' (suicide) and 'externalised violence' (homicide/femicide). Suicide was more prevalent in modern individualistic and less regulated societies where the influences of religion and family and political life were weaker, and 'egoistic' behaviour more common. Homicide, on the other hand, depends on opposite conditions. Where 'family spirit has retained its ancient strength' the practice of vendetta survives, and 'where religious faith is very intense, it often inspires murders and this is also true of political faith' (Durkheim, 2002: 323) He concluded that high rates of homicide confer 'a sort of immunity against suicide' (Durkheim, 2002: 317). While recognising that suicide and homicide sometimes 'react under the same conditions in the same way' he nevertheless felt that 'the antagonistic cases are the most numerous' (Durkheim, 2002: 322; see also Whitt, 1994). ${ }^{3}$

\section{Beyond Social Integration}

One criticism of Durkheim's sociology is its insistence that individual psychology plays no part in explaining the nature and prevalence of suicide. For example, Lane argues that it is essential to consider the psychology of frustration and aggression in understanding whether violence is directed at others or internalised. His study of Philadelphia shows that between 1870 and the end of the century, after decades of ethnic and economic turbulence, the suicide rate more than doubled and there was a pronounced drop in homicides. After 1870, Philadelphia not only became a more ordered and regulated city, but also its people were increasingly (and variously) socialised into the behavioural disciplines required of the new industrial work force 
(Lane, 1979: 120-3). In these new conditions individuals were more likely to internalise frustration and aggression, hence the increase in suicide. Whereas Durkheim saw higher suicide rates caused by the less regulated, 'anomic' nature of modern industrial society, Lane argues the reverse by proposing that this 'fatalistic suicide' was the product of an integrated, constraining environment. This type of suicide merits only a footnote in Durkheim's study (2002: 239).

A second challenge to Durkheim is that integration theory fails to link social forces and individual experience. The concept that brings the two together is 'social isolation' which is both the result of social factors and, through loneliness and depression, prevents individuals from accessing social support (Bailey, 1998: 257). Social isolation, linked to social factors and the life cycle, is the central concept in Sainsbury's study of suicide in 1950s London in which he writes of 'the social and cultural isolation of the immigrant; the solitude of old age (...); the unemployed's sense of social rejection' (Sainsbury, 1971: 254). The concept has been operationalised in three measures - the proportion of the population that has recently migrated, lives alone and is not in work (Dorling and Gunnell, 2003). Patterns of social isolation have changed historically as the experience of the life cycle itself changes. This can be seen in the shifting profile of suicides towards younger age groups observable in many countries, a trend which expresses a profound change in the relative insecurities of younger and older people (Baudelot and Establet, 2008 :194).

The most forceful attack on Durkheim comes from those who reject official statistics as representing the social facts of suicide. Most empirically-based studies of war and suicide do not question the validity of official records or discuss the impacts that war may have on the process of gathering and classifying suicide statistics. Durkheim was aware of this point but saw it as a relatively insignificant one. His language is 
interesting. The 'paralysis in administration' as a possible cause of a fall in suicides at the start of war is described as an 'accidental cause' and a 'mistake in accounting' (Durkheim 2002: 164-5). It is also clear from his analysis of monthly suicide statistics that he regarded official figures as a sensitive barometer of political crises and events (2002: 162-3).

Against this, Douglas argued that official suicide statistics, far from showing real rates and trends, should be seen as the product of a social process of negotiation, interpretation and definition. Because suicide is socially stigmatised, families will seek to avoid suicide as a categorisation but they will have varying degrees of success, according to social position. Douglas proposed that 'the greater degree of social "integration" of a group, the lower will be its official suicide rate as a result of the official categorization process itself' (his emphasis) (Douglas, 1971: 129). Public officials involved in the judgement of suicidal intent are heavily influenced by commonsense assumptions and shared social meanings (Bailey, 1998: 23). Further, 'medical authorities protect their authority by determining suicide conservatively' (Timmermans, 2005: 311).

The social process of suicide classification reflects assumptions about gender (Canetto and Sakinofsky, 1998). Divergent gendered expectations about suicidal behaviour may affect both the choices of the suicidal as well as the interpretations of doctors, coroners and others. Most studies tend to exclude the bulk of suicidal behaviour because of the focus on completed suicides. This especially affects women and leads to spurious conclusions about women's social integration and contentment with their social roles (Kushner and Sterk, 2005: 1141). For instance, recently collected data on self-harming presentations at hospitals in Northern Ireland give a higher rate for women than for men (Northern Ireland Registry of Deliberate Self-Harm, 2010). 
Douglas's approach has been applied in the Northern Ireland context. Prior (1985: 186) observed coders of death certificates in Belfast in the early 1980s and suggests there are 'fundamental flaws' in the process of death registration. More recently, O'Connor and Sheehy's work on gender and suicide (1997: 240) refers to 'quite a large discrepancy between the official classification (...) and the picture presented by inquest papers'. As with Douglas, the implication is that the official figures provide unreliable data on the dead.

It is tempting to dismiss suicide statistics as of little value to a sociological analysis. There are two major arguments against this position. The first is that despite the inconsistencies of doctors, coroners and coders, and the influence of families and others, there remains sufficient accuracy for analytical purposes (Sainsbury and Jenkins, 1982: 44). Secondly, the process of critically analysing suicide data, especially in periods of armed conflict, may reveal significant observations about the social context of suicide. Suicide statistics, whatever their limitations, are an important tool of analysis as long as their social construction is acknowledged and incorporated into the analysis.

\section{War, Peace and Suicide}

Much of the recent work on war and suicide retains an emphasis on Durkheim's concept of social integration, paying little attention to individual motivation and variations in the meaning that specific social conditions may have for different groups of people. But the concept has been modified to accommodate the changing character of armed conflicts since Durkheim's day and the relative impacts on civilians and combatants. There has also been increasing interest in the psychological consequences of war for frontline combatants and civilians (Abi-Rached, 2009). 
Van Tubergen and Ultee (2006) reviewed the 'war and suicide' literature, focusing largely on the First and Second World Wars. They point out that a drop in suicides is observable in the non-belligerent countries, that suicides fluctuate considerably during the two wars (especially at the start and end) and that a fall in suicides may be the result of changes in economic activity rather than political integration (2006: 223). This is Marshall's (1981) explanation for why suicide rates in the United States went down during the Second World War but not during the Korean and Vietnam wars. Van Tubergen and Ultee conclude that 'a war might cause certain groups to fear being excluded from society, and this fear could result in higher suicide rates among these groups' (2006: 226).

Another strand of 'war and suicide' research focuses on the psychological impacts of actual and anticipated violence, including the behaviour of combat troops. The conditions of war vastly increase the means available for suicide as well as the frequency of desperate and inescapable situations. Henderson et al. (2006) found that the male suicide rate in Scotland rose between 1940 and 1943, especially in the under 45 year old age group. This was against the long-term trend and the means of suicide proved to be critical: 'firearms and explosives' was the only method that increased significantly during the War. Female suicide trends were unaffected by the War.

In Nazi Germany the number of suicides varied greatly as the War progressed. In the 1920s and 1930s, there was an obsession with rising suicides rates and the issue became 'a propagandist lever across political divides, and a routine signifier of Weimar misery' (Goeschel, 2009: 29) - Hitler explicitly linked suicides to the hardships caused by the Versailles Peace Treaty. Then at the start of the Second War suicides fell but as German military successes were halted and reversed, suicides, including those of German Jews facing deportation, rose once more. ${ }^{4}$ In the spring of 1945 , suicides 
reached epidemic proportions both from fear of the advancing Red Army and as a consequence of its arrival. At least two million German women are believed to have been raped at this time, many of them repeatedly. In Berlin around 100,000 women were raped and 10,000 of them died, mostly from suicide (Beevor, 2003: 410).

The availability of firearms during and after the war years was an important factor in explaining the elevated suicide rates in Serbia and Montenegro, but unlike Scotland, these were associated with older rather than younger age groups (Selakovic-Bursic et al., 2006). The male/female suicide differential was low (2:1) and actually narrowed slightly during the first war period (1991-94).

Studies of suicides among combat troops are uncommon ${ }^{5}$ although it is evident that low morale and poor mental health are key concerns of military leaders. There is great political sensitivity over military suicides because such 'weaknesses' may be exploited by military and ideological opponents. The psychological impact of war is a highly contested area with some writers arguing against the screening of recruits and 'overprecautionary' protections from the stresses of combat (Wessely, 2005). Studies of combatants in Iraq and Afghanistan show contradictory results. A team studying members of the UK's Air Assault Brigade claim that mental health improved as a result of combat (Hughes et al., 2005), contrary to findings on U.S. combat troops (Hoge et al., 2004). Kang and Bullman (2008) found that the overall risk of suicide among U.S. veterans was not significantly different from the general population. This is contradicted by Bruce's finding that military service, by increasing injury and long-term disability, increases the risk of depression, joblessness, and social isolation-'all of which together increase suicide risk' (Bruce, 2010: 102). She specifically argues that it is not entering or being in the military that increase suicide risk but the long-term 'downstream sequelae' of military experience. 
Braswell and Kushner take issue with this by suggesting that social integration within masculine military culture is itself 'a key factor in the currently high rates of (U.S.) military suicides' (2010: 5). All of the stress factors of recent deployments (Iraq and Afghanistan), including combat trauma, more frequent deployments and personal relationship difficulties, may be connected to the military's 'fatalistic masculinity' and the 'excessive regulation' associated with it (Kushner and Sterk, 2005).

While there is some disagreement over the U.S. military suicide statistics, the more significant issue is the different explanations being advanced for the recent suicide 'epidemic'. Is it oppressive military culture or the disabling psychological consequences of war? This is not simply a debate between sociological and psychological approaches as each suggests different types of intervention: reform of the "warrior ethos' in the former and stronger psychiatric support in the latter. In the case of militarised conflicts, however, given the complexities of social and individual consequences, there is clearly a case to explore the strengths of both perspectives in accounting for suicides and in seeking to prevent them.

\section{Suicide and the Northern Ireland Conflict}

There are several studies that deal with suicide and the Northern Ireland conflict, and generally these accept the official statistics as providing the social facts on suicides. Lester (2002) correlated suicide rates with the numbers killed each year as a result of the conflict. Broadly speaking, suicide rates were higher when conflict deaths were lower but there is also a period in the early years when conflict deaths rose sharply while suicide rates went down.

Similarly, Mcgowan et al. (2005) correlated coroners' suicide verdicts with 'terroristrelated deaths'. Official figures were used for suicides but not for the conflict killings 
which were drawn instead from a book compiled by four journalists (McKittrick et al., 1999). A statistically significant inverse relationship was found for both men and women, and, in traditional Durkheimian fashion, the authors propose that 'the Troubles affected a social cohesion and ghettoization' that had the effect of protecting people from suicide (McGowan et al., 2005: 404). In contrast, O'Connor and Sheehy (1997) argue that the demographic, and specifically gender, profile of suicides in Northern Ireland is similar to that in Great Britain and Ireland, suggesting there is no conflictrelated effect.

\section{Suicide Trends and the Reliability of Data}

Figure 1 shows suicide rates per 100,000 of the Northern Ireland population for the period 1967 to 2008, based on three-year rolling averages. ${ }^{6}$ Between 1965 and 2008, the number of suicides registered in Northern Ireland was 6,131 of which 1,751 were female suicides (a male to female ratio of 3.5:1). Over the period of the conflict, there were about a thousand more suicides than conflict-related killings.

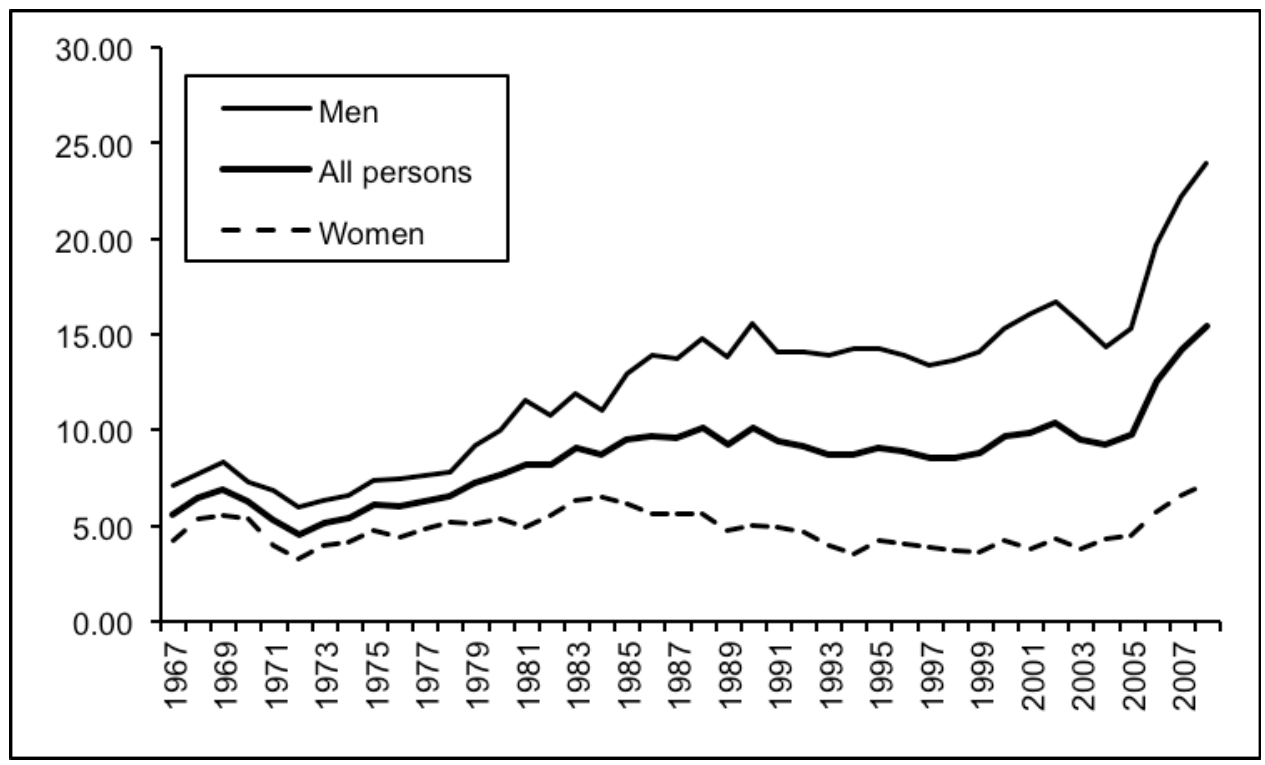

Figure 1 Northern Ireland Suicide Rates by Gender, 1967-2008

Source: Compiled from Registrar General Northern Ireland Annual Reports

The reliability of the official suicide statistics in Northern Ireland is shaped by two main factors. The first is the time it takes for a death to be recorded as a suicide. The 
majority of suicides registered in a given year do not occur in that year and there is no significant correlation between occurrence and registration data, suggesting that delays in registration are not consistent. Thus any attempt to relate suicides to contemporaneous events and short-term trends using the registered suicide data is fraught with difficulty.

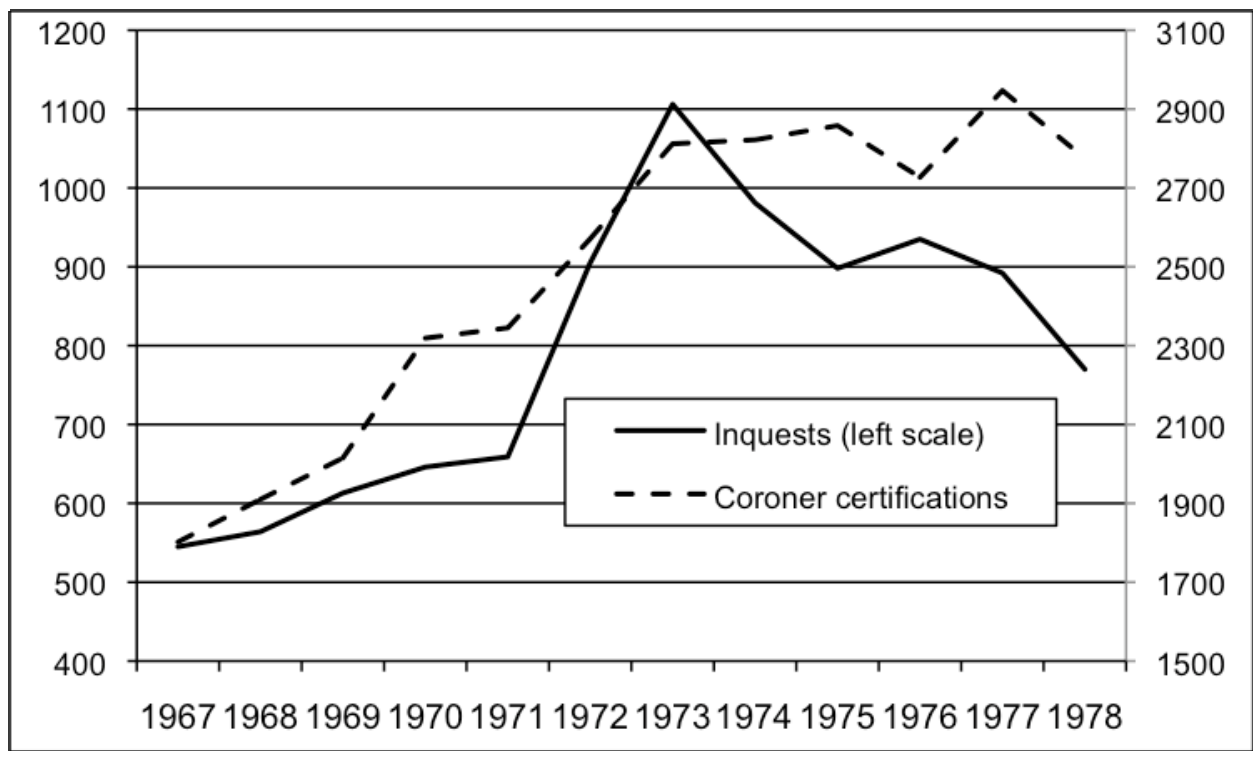

Figure 2 Coroner's Office activity in the 1970s (number of cases)

Source: Compiled from Registrar General Northern Ireland Annual Reports

In the early years of the conflict the problem was especially acute because of the rapid increase in deaths from 'external causes'. ${ }^{7}$ The number of inquests doubled between 1968 and 1973 (Figure 2). Inevitably, the registration of violent deaths was affected as coroners became flooded with work. Figure 3 indicates a time lag of three years or more between occurrences and registrations for conflict-related killings. Inquests for suicides, caught up in the backlog of cases, would have delayed suicide registrations in the same way. Therefore, the 1970s registered suicide data are particularly unreliable for judging suicide occurrences and suicide trends. 


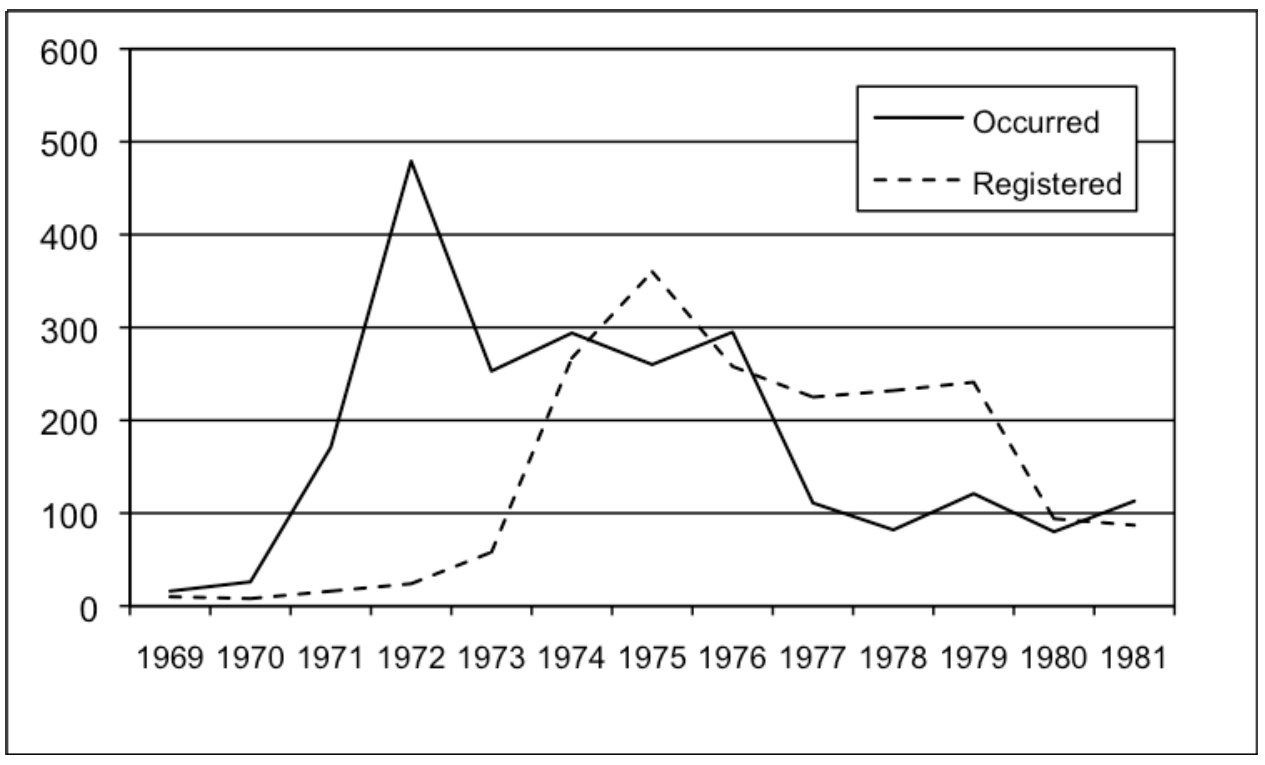

Figure 3 Conflict-related deaths, occurred and registered (numbers) ${ }^{a}$

a The conflict-related deaths are 'homicides' added to deaths from 'injury resulting from operations of war' (International Classification of Diseases conventions).

Source: Compiled from Registrar General Northern Ireland Annual Reports and Sutton (1994)

The second major issue of reliability is the problem of determining the cause of death. A death from poisoning, for example, could be classified as a 'suicide' or an 'accident'. From 1968 a third possibility, 'events of undetermined intent', was introduced to accommodate cases likely to be suicides but where doubts remained.

The proportion of suicides that are 'undetermined' was particularly high between 1972 and 1983, reaching 36 per cent in 1980. This could be explained by changes in the cause of death over time as some causes are more likely to attract the 'undetermined intent' classification (e.g. 'drowning' and 'firearms and explosives'). For drowning, there is also a significant gender difference in the undetermined proportion, indicating that coroners are almost twice as likely to avoid a definite determination of suicide by drowning for men as they are for women. For all causes of death other than poisoning, however, there are now lower proportions of undetermined suicides in the registered data. The most likely explanation for the high undetermined rate in the early period of conflict is that coroners used the category more readily, and perhaps more casually, 
due to pressure of business.

There is another reason to believe that the registration of suicides was particularly unreliable in the early 1970s. Curiously, the number of registered accidental poisonings increased by three times between 1969 and 1972, while suicides by poisoning reduced by more than half. The suspicion must be that some suicides from poisoning were misclassified as accidents. There is a strong inverse relationship between 'determined suicides' and 'accidents' plus 'undetermined suicides' (Table 1). ${ }^{8}$

Table 1 Pearson correlation coefficients for poisonings registered as accidents and suicides

\begin{tabular}{|l|c|c|c|}
\hline$R$ values & $\begin{array}{c}1964-1984 \\
(n=21)\end{array}$ & $\begin{array}{c}1964-1979 \\
(n=16)\end{array}$ & $\begin{array}{c}1968-1984 \\
(n=17)\end{array}$ \\
\hline $\begin{array}{l}\text { a) Accidents + Undetermined Suicides } \\
\text { b) Determined Suicides }\end{array}$ & $-0.650^{* *}$ & $-0.670^{* *}$ & $-0.571^{*}$ \\
\hline $\begin{array}{l}\text { a) Accidents } \\
\text { b) Determined + Undetermined Suicides }\end{array}$ & $-0.554^{* *}$ & $-0.599^{*}$ & $-0.541^{*}$ \\
\hline
\end{tabular}

*Significant at .05 level (2-tailed); ${ }^{* *}$ significant at .01 level (2-tailed)

Source: Calculated from Registrar General Northern Ireland Annual Reports

From the late 1970s, the registration of suicides is less disrupted and becomes more reliable. The published suicide statistics have further limitations, however. The published data record suicides and deaths of undetermined intent by age and gender. The cause of death, using International Classification of Diseases (ICD) categories, is also provided. But no information is given on religion, social class or occupation, and individual records would need to be examined to derive such variables.

\section{Suicide Trends Analysis}

Figure 4 identifies three distinct periods for the all-persons suicide rate from 1978 onwards. For the first period, there is a steady increase $(y=0.33)$ with a closely fitting trend line $\left(R^{2}=0.94\right)$ up to a rate of $10.1(1988)$, followed by a modest downturn $(y=-$ 0.14) for a further ten years to a rate of 8.6. The steep upward trend in the postAgreement period appears to be interrupted by the values for 2003-2005, though the $R^{2}$ value over ten years is still relatively high at 0.69 . Again, administrative factors are partly responsible as the occurrence data show 2003 as the only year that is 
significantly off trend. The reorganisation of the Coroners Service was in progress at this time.

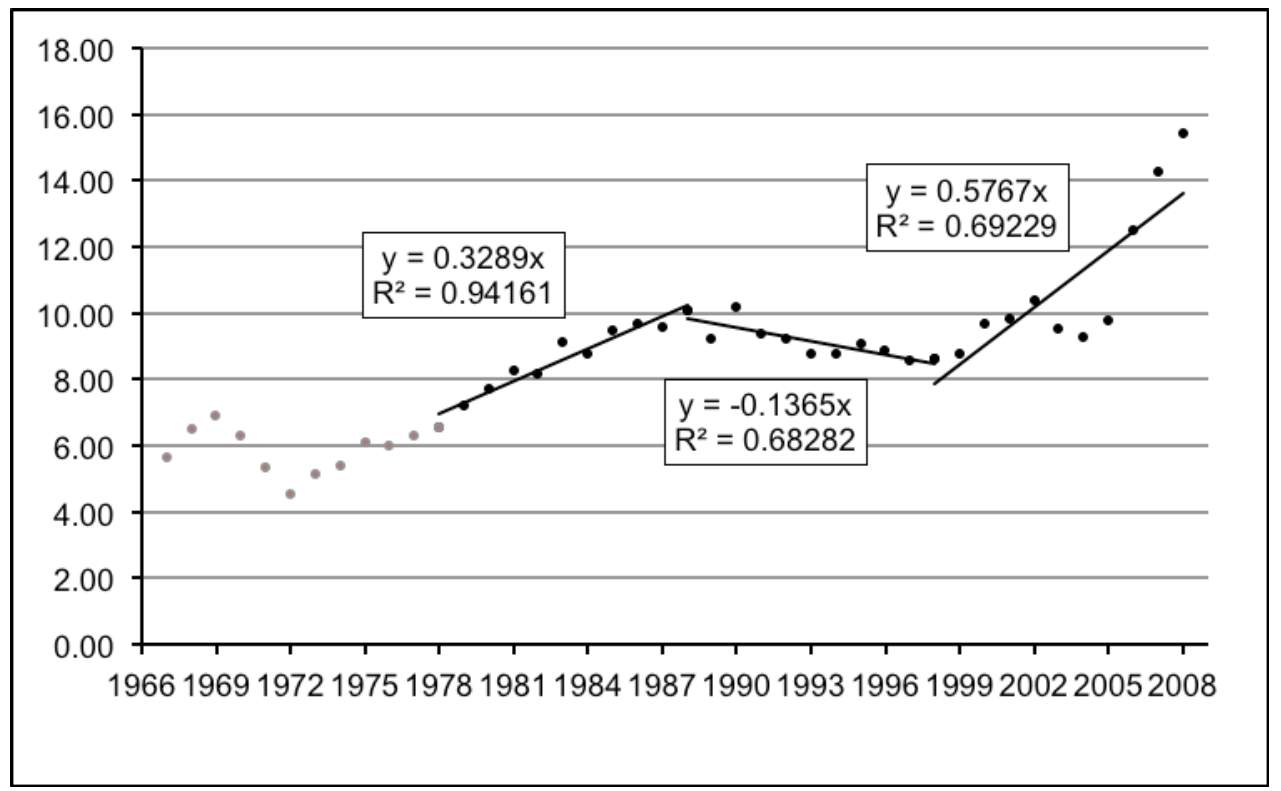

Figure 4 Trends in Suicide Rates (all persons, three year rolling averages) Source: Compiled from Registrar General Northern Ireland Annual Reports

Taking Figure 4 as a model, trend values were calculated for a range of age groups for men and women for each of the periods (Table 2). The strongest trends upwards are for men aged 45-54 (y=2.14) and 35-44 (y=1.89) in period three. These groups were aged $15-24$ and 5-14 in the 1970s.

Table 2 also illustrates that suicide rates for older groups have declined over time while those for younger to middle aged groups have increased. The highest top rate in period three is for men aged $35-44$ (38.9) followed closely by the $25-34$ and $45-54$ age groups (37.1 and 35.5 respectively). The pattern for women follows this exactly, except that the age band is one group higher in every case. 
Table 2 Slope and linear regression values by gender and age bands

\begin{tabular}{|c|c|c|c|c|c|c|c|c|c|}
\hline & \multicolumn{3}{|c|}{ Period 1 (1978-1988) } & \multicolumn{3}{|c|}{ Period 2 (1988-1998) } & \multicolumn{3}{|c|}{ Period 3 (1998-2008) } \\
\hline Age Group & $\begin{array}{l}\text { Slope } \\
\text { (y) }\end{array}$ & $\mathrm{R}^{2}$ & $\begin{array}{c}\text { Rate Range } \\
\text { (Average) }\end{array}$ & $\begin{array}{l}\text { Slope } \\
\text { (y) }\end{array}$ & $\mathrm{R}^{2}$ & $\begin{array}{c}\text { Rate Range } \\
\text { (Average) }\end{array}$ & $\begin{array}{l}\text { Slope } \\
\text { (y) }\end{array}$ & $\mathrm{R}^{2}$ & $\begin{array}{l}\text { Rate Range } \\
\text { (Average) }\end{array}$ \\
\hline All Persons & 0.33 & 0.94 & $\begin{array}{c}6.56-10.1 \\
(8.6)\end{array}$ & -0.14 & 0.68 & $\begin{array}{c}8.57-10.1 \\
(9.2)\end{array}$ & 0.58 & 0.69 & $\begin{array}{c}8.6-15.45 \\
(10.7)\end{array}$ \\
\hline All Men & 0.61 & 0.92 & $\begin{array}{c}7.82-14.77 \\
(11.6)\end{array}$ & -0.11 & 0.38 & $\begin{array}{c}13.41-15.57 \\
(14.1) \\
\end{array}$ & 0.85 & 0.67 & $\begin{array}{c}13.62-23.98 \\
(17.0)\end{array}$ \\
\hline All Women & 0.08 & 0.27 & $\begin{array}{c}4.96-6.49 \\
(5.7)\end{array}$ & -0.17 & 0.75 & $\begin{array}{c}3.58-5.65 \\
(4.4)\end{array}$ & 0.32 & 0.74 & $\begin{array}{c}3.65-7.25 \\
(4.7)\end{array}$ \\
\hline Men 15-24 & 0.52 & 0.38 & $9.96-19.55$ & 0.44 & 0.28 & $14.76-24.25$ & 0.12 & 0.01 & $15.64-28.13$ \\
\hline Women 15-24 & 0.17 & 0.39 & $2.31-5.48$ & -0.21 & 0.43 & $2.16-5.48$ & 0.14 & 0.09 & $2.51-7.13$ \\
\hline Men 25-34 & 1.00 & 0.80 & $9.42-20.96$ & 0.30 & 0.33 & $20.96-25.73$ & 0.55 & 0.20 & $25.73-37.05$ \\
\hline Women 25-34 & -0.29 & 0.50 & $4.02-8.43$ & -0.13 & 0.57 & $2.85-4.79$ & 0.47 & 0.67 & $3.89-9.29$ \\
\hline Men 35-44 & 0.82 & 0.75 & $12.16-22.19$ & -0.11 & 0.10 & $16.24-19.87$ & 1.89 & 0.80 & $16.41-38.93$ \\
\hline Women 35-44 & 0.34 & 0.60 & $5.96-10.1$ & -0.12 & 0.43 & $6.47-8.64$ & 0.27 & 0.19 & $5.2-12.17$ \\
\hline Men 45-54 & 1.33 & 0.85 & $10.2-24.96$ & -0.43 & 0.37 & $13.08-20.58$ & 2.14 & 0.90 & $14.39-35.47$ \\
\hline Women 45-54 & -0.38 & 0.77 & $9.62-13.8$ & -0.34 & 0.48 & $7.22-12.24$ & 0.57 & 0.74 & $5.79-12.91$ \\
\hline Men 55-64 & 0.34 & 0.18 & $14.46-23.7$ & -1.73 & 0.73 & $11.85-32.89$ & 1.28 & 0.56 & $8.1-23.82$ \\
\hline Women 55-64 & 0.26 & 0.03 & $7.92-20.25$ & -0.37 & 0.73 & $3.45-8.25$ & 0.72 & 0.67 & $2.43-10.32$ \\
\hline Men 65-74 & 0.11 & 0.02 & $12.40-21.54$ & -0.47 & 0.47 & $11.13-18.19$ & 0.02 & 0.00 & $8.71-14.18$ \\
\hline Women 65-74 & 0.32 & 0.27 & $6.1-12.76$ & -0.43 & 0.46 & $3.9-11.19$ & 0.19 & 0.27 & $2.91-6.20$ \\
\hline Men 75 and over & 1.69 & 0.89 & $2.99-20.61$ & -0.67 & 0.45 & $7.99-20.36$ & 0.51 & 0.60 & $6.70-14.36$ \\
\hline $\begin{array}{l}\text { Women } 75 \text { and } \\
\text { over }\end{array}$ & 0.09 & 0.07 & $1.43-4.94$ & -0.20 & 0.30 & $0.54-4.94$ & 0.17 & 0.34 & $0.53-2.91$ \\
\hline
\end{tabular}

Source: Compiled from Registrar General Northern Ireland Annual Reports

Notes: i) Age band rates standardised by population in relevant age band; ii) Figures in bold are against the overall trend.

To explore possible cohort affects Table 3 shows average suicide rates for six age bands over four periods. ${ }^{9}$ Cohort 3 has an increased rate in every decade for men and women. The pattern for Cohorts 4-6 is an increase between the first and second decades but a decline for every decade thereafter (with the exception of Cohort 4 for women). Again, this pattern applies to men and women in a remarkably consistent fashion. ${ }^{10}$

The equivalent of Cohort 3 is the group aged 25-34 shown in period one of Table 2 and the 35-44 age group in period two. This cohort has a well above average increasing suicide rate $(y=1.00)$ in period one, an average decline $(y=-0.11)$ in period two and a 
sharply increasing trend in period three $(y=2.14)$. Cohort 2, aged 15-24 in period one, had a rising suicide rate $(y=0.30)$ in period two, against the downward trend, and a rapidly increasing rate $(y=1.89)$ in period three.

Table 3 Average suicide rates for age cohorts by decade

\begin{tabular}{|c|c|c|c|c|c|c|}
\hline $\begin{array}{l}\text { Age at first } \\
\text { decade of } \\
\text { conflict }\end{array}$ & $\begin{array}{c}\text { First } \\
\text { decade } \\
1968-1978\end{array}$ & $\begin{array}{c}\text { Second } \\
\text { decade } \\
1978-1988\end{array}$ & $\begin{array}{c}\text { Third } \\
\text { decade } \\
1988-1998\end{array}$ & $\begin{array}{c}\text { Fourth } \\
\text { decade } \\
1998-2008\end{array}$ & $\begin{array}{l}\text { Percentage } \\
\text { change } \\
\text { between first } \\
\text { and second } \\
\text { decade }\end{array}$ & $\begin{array}{l}\text { Percentage } \\
\text { Change } \\
\text { between } \\
\text { second and } \\
\text { fourth decade }\end{array}$ \\
\hline & \multicolumn{6}{|c|}{ Men } \\
\hline $\begin{array}{l}\text { Cohort } 1 \\
\text { aged }<5\end{array}$ & & & 19.7 & 29.8 & & \\
\hline $\begin{array}{l}\text { Cohort } 2 \\
\text { aged 5-14 }\end{array}$ & & 12.8 & 23.1 & 25 & & +95 \\
\hline $\begin{array}{l}\text { Cohort } 3 \\
\text { aged } 15-24\end{array}$ & 6.8 & 15.9 & 17.6 & 23.3 & +134 & +47 \\
\hline $\begin{array}{l}\text { Cohort } 4 \\
\text { aged } 25-34\end{array}$ & 7.7 & 17.4 & 16.7 & 14.3 & +126 & -17 \\
\hline $\begin{array}{l}\text { Cohort } 5 \\
\text { aged } 35-44\end{array}$ & 11.4 & 17.1 & 18.9 & 11.6 & +50 & -32 \\
\hline $\begin{array}{l}\text { Cohort } 6 \\
\text { aged } 45-54\end{array}$ & 13.8 & 20.2 & 14.9 & 9.7 & +46 & -52 \\
\hline & \multicolumn{6}{|c|}{ Women } \\
\hline $\begin{array}{l}\text { Cohort } 1 \\
\text { aged }<5\end{array}$ & & & 3.6 & 6.7 & & \\
\hline $\begin{array}{l}\text { Cohort } 2 \\
\text { aged 5-14 }\end{array}$ & & 3.4 & 4 & 7.2 & & +111 \\
\hline $\begin{array}{l}\text { Cohort } 3 \\
\text { aged } 15-24\end{array}$ & 2.8 & 6.3 & 7.7 & 8.7 & +125 & +38 \\
\hline $\begin{array}{l}\text { Cohort } 4 \\
\text { aged } 25-34\end{array}$ & 4.3 & 7.8 & 9.4 & 5.2 & +81 & -33 \\
\hline $\begin{array}{l}\text { Cohort } 5 \\
\text { aged } 35-44\end{array}$ & 7.8 & 11.4 & 6.3 & 4.1 & +46 & -64 \\
\hline $\begin{array}{l}\text { Cohort } 6 \\
\text { aged } 45-54\end{array}$ & 9.5 & 12.8 & 6 & 2.2 & +35 & -83 \\
\hline
\end{tabular}

For women, Cohort 3 has a declining rate $(y=-0.29)$ against the trend in period one but shows an above average rise in period three. Cohort 4 (aged 35-44 in period one) has an above average rising suicide rate $(y=0.34)$ in period one, a relatively strongly declining rate in period two $(y=-0.34)$ and a rate with the fastest increase out of all the female age groups $(y=0.72)$ in period three.

The data in Tables 2 and 3 therefore point towards a strong cohort affect for men who were children or young adults during the worst years of the conflict. The affect is 
observable for women, though it is weaker and complicated by differences in withindecade trends. ${ }^{11}$

\section{Explaining Suicide Trends}

In summary, there are a number of changes in the social pattern of suicides that require explanation. What explains the rise in overall rates in period one, the decline in period two and the much steeper rise in period three which follows the 1998 Agreement? Secondly, why has the gender gap in suicide rates grown and thirdly, why has the age profile of suicide rates changed, especially the trend towards younger age groups among men? Finally, what explains the consistent rise in suicide rates for the cohorts of men and women who were aged 5-24 during the first decade of conflict? The overarching question for this paper is what bearing does the conflict and the transition to peace have on any of these findings?

In terms of how the conflict affected the trends in Figure 4, it is difficult to differentiate one development from another and to argue that they had distinct affects on the 'collective force... impelling men to self destruction' (Durkheim, 2002: 263). More likely, a combination of factors are at play.

Period one is characterised by a decline in IRA killings, ${ }^{12}$ and the adoption of new counter-insurgency measures. More than 5,000 people were being committed to prison each year - a figure that peaked at over 6,000 in 1987 - and hundreds were serving life sentences (Tomlinson, 1995: 201-7). Coulter (1991) provides a rare account of the impact on children and families, including suicide attempts of women. At the same time, the economy was faltering with unemployment rising steeply from under 6 per cent in the mid-1970s to over 21 per cent by 1984, approaching levels reached in the 1930s. The social isolation of unemployment is an established risk factor for suicide (Lewis and Sloggett, 1998; Blakely et al., 2003), as are economic shocks and 
insecurity (Stuckler et al., 2011). Yet the data above show declining suicide rates in two of the core working age groups for women. Part of the answer is that in the early 1980s, female unemployment was less severe than for men and female employment recovered more quickly, continuing to expand until the 2008 recession (Department of Trade and Investment, 2010: 6).

The overall decline in suicide rates in period two is mainly accounted for by the sharper decline in rates for older men and women than for the younger groups (Table 2). Two male age groups (15-24 and 25-34) show rising rates, against the trend for all other groups. It is difficult to relate these age affects to political circumstances. The conflict was essentially at stalemate during much of period two, punctuated by an upsurge in killings by non-state, pro-Union armed groups and growing evidence of collusion by elements within the state security forces (Cory Report, 2004). More plausibly, the increase in male suicides in the younger working age groups is associated with faltering employment prospects: economic inactivity for men shows a broad upward trend during the 1990s.

The steep upward trend in suicide rates in the post-1998 period is not associated with unemployment as there was a sustained increase in employment for most of the period up to 2008 and a sense of economic prosperity not experienced for decades. This relatively rapid economic change is accompanied by profound political change following the gradual implementation of the 1998 Agreement. Rather than seeing this period as more anomic and less socially integrated than the decades of conflict, the transition to peace arguably involves greater social cohesion, political integration and stability. Political stability has rested on a broad-based embracing of equality as well as the specific commitment to peace by political and military actors (Campbell, 2008). For the wider population, everyday life which for decades had been framed by varying 
degrees of fear, threat and polarised political life, became safer and more predictable. Open expressions of hatred, domination and violence became less socially acceptable.

Regarding the widening gender gap in suicides, the long-term rise of the employment rate for women and the more checkered pattern for men provides part of the explanation, as indicated. It may also be that the conflict - as a result of imprisonment, migration and the individual and collective stresses of violence - exacerbated a number of trends contributing to social isolation. In period one, for example, the annual number of divorces increased three-fold; by the end of the 1990s they were up fivefold. Men of working age are now twice as likely to be living alone than women, while the proportion of families headed by a lone mother increased from 10 to 23 per cent between 1983 and $1998 .^{13}$

The final issue concerns the cohort affect identified above. All age cohorts increased their suicide rates between the first and second decades of the conflict but by different factors (Table 3). From the second decade onwards, average suicide rates declined for most cohorts, except the youngest; and the older the cohort, the greater the decline suggesting age-related resilience. It seems reasonable to suggest that there was a population-wide conflict-related affect on the cohort of children and young people who were growing up in the first decade.

There is a pathway linking political and social division to individual psychology. In the case of Northern Ireland, politics, employment, residential space, and social and cultural activities have all been shaped by division and violent conflict to such an extent that there have been two profound psychological impacts (Hamber, 2004). First, everyday life is highly politicised and all sides of the political divide have sanctioned violence in its various forms. Secondly, there is a 'legacy of authoritarianism' observable at the individual level, within communities and at the level of the state. 
These effects will be strongest for those who grew up in the conflict and who experienced no other social context until the 1990s. In the period of peace, externalised expressions of the cultures of violence and authoritarianism have gradually subsided and to some extent violence has become internalised.

The conflict-related stresses of everyday life were particularly acute among those who were in the frontline of the conflict. While there have been various claims regarding trauma and suicides, there are no systematic studies of combat troops, police officers and others. ${ }^{14}$ But there is survey evidence that those who experienced or witnessed the most violence have poorer mental health than those with the least experience (Miller et al., 2003; Muldoon et al., 2005) and are more likely to be economically disadvantaged (Hillyard et al., 2005).

There are other symptoms and promoters of poor mental health. The transition to peace has involved mass medication with anti-depressants, alcohol and nonprescription drugs. The volume of prescribed anti-depressants increased by six times between 1989 and 2000 (National Advisory Committee on Drugs, 2003). Alcohol consumption, particularly by men has risen dramatically since the 1990s, with more than a third of working age men under 45 drinking above safe limits. While this may be attributed to more relaxed licensing laws and post-1998 economic gains, it may also relate to the decline of traditionally strong pioneer and temperance movements (Smith and Foxcroft, 2009). In addition, there is the argument that drug use and the illicit drugs trade have flourished during the peace process (Higgins et al., 2004).

\section{Conclusion}

Few studies of war and suicide have tackled the sociological intricacies of divided societies characterised by sustained violent conflict, or have paid serious attention to the impact of peace on suicide trends. This case study of Northern Ireland examined 
suicide trends by age, gender and cause of death over a forty-year period. The key finding is that the steep upward trend in suicide rates after the 1998 Agreement is associated with the conflict in a number of ways that take us beyond traditional Durkheimian 'war and suicide' sociology.

The first point is that militarised conflicts and widespread political disturbances not only disrupt the compilation of suicide statistics but also shape the assumptions and decisions of key actors in the process of recording and adjudicating death. To neglect this point is to make spurious connections between short-term trends and conflictrelated events, including killings.

Secondly, sustained conflicts have distinct effects on economic and social structures. In the case of Northern Ireland the conflict sharpened divisions in employment and unemployment, and, through specific experiences such as imprisonment, it increased social isolation at the level of families and households. Understanding the gendered experience of war and peace, therefore, is crucial to making sense of the male/female patterns of self-harming and completed suicide, and changing trends across the life cycle.

Third, wars often involve extreme situations that produce suicides, such as in 1945 Berlin, and they also produce short-term reactions to the pressures of military culture. What tends to be neglected is the long-term impact of violence on the broader social culture. It is not simply that the 'long-term sequelae of war traumas have been underestimated' (De Jong, 2002: 42). The main finding of the case study is that the cohort of children and young adults growing up in the worst years of violence now have the highest suicide rates and the most rapidly increasing rates. These generations were the most acculturated to division and conflict, and to externalised expressions of aggression. The consequence of peace is that such expressions of aggression and 
violence are no longer socially approved. They become internalised instead.

Finally, we need to distinguish between the social changes that wars bring about and contribute to, and the direct effects of war on the mental health and behaviour of individual witnesses, survivors and perpetrators of violence. Durkheim's social integration theory continues to influence the analysis of suicide but sits uneasily alongside the complexities of contemporary wars and within country violent conflicts. In the quest to establish and privilege sociological over psychological explanations, a Durkheimian approach goes against what is most needed in research on war, peace and suicide: multidisciplinary insights that move us beyond the polarity of sociology and psychology, and illuminate the psychosocial pathways that link social structure and process to individual meaning and action.

\section{Notes}

1. The Good Friday Agreement (or Belfast Agreement) was popularly endorsed by referendums held in the Irish Republic and Northern Ireland which had been governed directly by Britain since 1972 .

2. Egoistic suicide arises from an excess of individualism, less likely in conditions of war. Anomic suicide stems from a lack of social regulation typically arising from a period of rapid change, especially economic change, during which established norms and values become less relevant and powerful at both social and individual levels (see Baudelot and Establet, 2008).

3. Bills and $\mathrm{Li}(2005)$ examined the association between homicide and suicide for 65 countries, finding a weak statistical relationship overall. 
4. Goeschel attributes the increase in suicides to the waves of deportations of German Jews, hardships caused by the Allied bombing of towns from 1942 (destroying the housing of a third of the population), demoralisation following the defeat at Stalingrad, and Nazi terror against foreigners.

5. For two recent exceptions by historians, see Padiak (2009) and Prestwich (2009).

6. The rate for 1967 is the average of 1965,1966 and 1967 rates. The figures include 'events of undetermined intent' as it is now conventional to count these as 'suicides'.

7. Doctors must refer such deaths to coroners who may decide to hold an inquest, a mandatory requirement in the case of suspected suicides until very recently.

8. This method was used by Sainsbury and Jenkins (1982) to assess the impact of the introduction of the 'undetermined intent' classification.

9. Table 3 (unlike Table 2) includes suicide rates for the first decade of the conflict as these are averaged out over an eleven-year period.

10. The Pearson correlation between men and women for percentage change between the second and fourth decades (last column) is highly significant $(r[2]=1.00, p<.01)$.

11. The distinction between cohort, age and period effects is discussed by Gunnell et al. (2003).

12. IRA killings fell from 93 in 1979 to 37 by 1986 .

13. Northern Ireland Statistics and Research Agency (various years) Continuous Household Survey. http://www.csu.nisra.gov.uk

14. The Police Federation claims that 'almost 70 officers have committed suicide, many of them with RUC-issued weapons' (http://www.royalulsterconstabulary.org/memorial.htm). Suicides among UK regular armed forces are analysed annually by the Defence Analytical Services Agency but no attempt is made to disaggregate specific theatres of conflict or combat experience (see Tomlinson, 2006: 102-3). Recent studies of ex-prisoners have drawn attention to poor mental health, linking it to experience of police interrogation and prison itself. (Grounds and Jamieson, 2003; Hamber, 2005; Shirlow and McEvoy, 2008) 


\section{References}

Abi-Rached, Joelle M. (2009) 'Post-War Mental Health, Wealth and Justice', Traumatology 15(4): 55-64.

Agreement, The (1998) Agreement reached in the multi-party negotiations. Belfast/Dublin: British/Irish Governments.

Bailey, Victor (1998) "This Rash Act". Suicide Across the Life Cycle in the Victorian City. Stanford: Stanford University Press.

Baudelot, Christian and Establet, Roger (2008) Suicide: The Hidden Side of Modernity. Cambridge: Polity Press.

Beevor, Anthony (2003) Berlin: The Downfall 1945. London: Penguin Books.

Bills, Corey B. and Li, Guohua (2005) 'Correlating homicide and suicide', International Journal of Epidemiology 34(4): 837-845.

Blakely, Tony A., Collings, Sunny C. D. and Atkinson, June (2003) 'Unemployment and suicide. Evidence for a causal association?' Journal of Epidemiology Community Health, 57: 594600.

Braswell, Harold and Kushner, Howard I. (2010) 'Suicide, social integration, and masculinity in the U.S. military', Social Science \& Medicine, doi: 10.1016/j.socscimed.2010.07.31

Bruce, Martha L. (2010) 'Suicide risk and prevention in veteran populations', Annals of the New York Academy of Sciences, 1208: 98-103.

Campbell, Beatrix (2008) Agreement: the State, Conflict and Change in Northern Ireland. London: Lawrence \& Wishart.

Canetto, Silvia S. and Sakinofsy, Isaac (1998) 'The Gender Paradox in Suicide', Suicide \& Life Threatening Behavior, 28(1): 1-23.

Cory Report (2004) Cory Collusion Inquiry Report, Patrick Finucane. House of Commons Paper 470. London: Stationery Office.

Coulter, Carol (1991) Web of Punishment: an investigation. Dublin: Attic Press. 
De Jong, Joop (2002) 'Public Mental Health in Low-Income Countries', in J. De Jong (ed) Trauma, War, and Violence: Public Mental Health in Socio-Cultural Context, pp. 2-5. New York: Plenum.

Department of Trade and Industry (Northern Ireland) (2010) Women in Northern Ireland. Belfast. http://www.detini.gov.uk/

Dorling, Daniel and Gunnell, David (2003) 'Suicide: the spatial and social components of despair in Britain 1980-2000', Transactions of the Institute of British Geographers, 28: 442460.

Douglas, Jack D. (1971) 'The Sociological Analysis of Social Meanings of Suicide', in A. Giddens (ed.) The Sociology of Suicide, pp. 121-151. London: Frank Cass.

Durkheim, Emile (2002) Suicide: A Study in Sociology. London: Routledge (first published 1897).

Goeschel, Christian (2009) Suicide in Nazi Germany. Oxford: Oxford University Press. Grounds, Adrian and Jamieson, Ruth (2003) 'No sense of an ending: Researching the experience of imprisonment and release among Republican ex-prisoners', Theoretical Criminology 7(3): 347-362.

Gunnell, David, Middleton, Nicos, Whitley, Elise, Dorling, Daniel and Frankel, Stephen (2003) 'Influence of cohort effects on patterns of suicide in England and Wales, 1950-1999', British Journal of Psychiatry, 182: 164-170.

Hamber, Brandon (2004) The Impact of Trauma: A psychosocial approach. http://www.brandonhamber.com

Hamber, Brandon (2005) "Blocks to the Future": A Pilot Study of the Long-term Psychological Impact of the 'No Wash/Blanket' Protest. Belfast: Action and Research International.

Henderson, Robert, Stark, Cameron, Humphry, Roger W. and Selvaraj, Sivasubramaniam (2006) 'Changes in Scottish suicide rates during the Second World War', BMC Public Health, 6: $167-74$

Higgins, Katherine, Percy, Andrew and McCrystal, Patrick (2004) 'Secular Trends in Substance Use: The Conflict and Young People in Northern Ireland', Journal of Social Issues, 60 (3): 485-506.

Hillyard, Patrick, Rolston, William J. and Tomlinson, Michael W. (2005) Poverty and Conflict in 
Ireland: An International Perspective. Dublin: Institute of Public Administration.

Hoge, Charles W., Castro, Carl A., Messer, Stephen C., McGurk, Dennis, Cotting, Dave I. and Koffman, Robert L. (2004) 'Combat duty in Iraq and Afghanistan, mental health problems and barriers to care'. New England Journal of Medicine 351: 13-22.

Hughes, Jamie H., Cameron, Fiona, Eldridge, Rod, Devon, Madeleine, Wessely, Simon and Greenberg, Neil (2005) 'Going to war does not have to hurt: preliminary findings from the British deployment to Iraq', British Journal of Psychiatry 186: 536-537.

Kang, Han K. and Bullman, Tim A. (2008) 'Risk of Suicide Among US Veterans After Returning From the Iraq or Afghanistan War Zones', Journal of the American Medical Association 300(6): 652-653.

Kushner, Howard I. and Sterk, Claire E. (2005) 'The Limits of Social Capital: Durkheim, Suicide and Social Cohesion', American Journal of Public Health 95(7): 1139-1143.

Lane, Roger (1979) Violent Death in the City: Suicide, Accident, and Murder in NineteenthCentury Philadelphia. Cambridge, Massachusetts: Harvard University Press.

Lester, David (2002) 'The "troubles" in Northern Ireland and suicide'. Psychological Reports 90 (3, Part 1): 722.

Lewis, Glyn and Sloggett, Andy (1998) 'Suicide, deprivation and Unemployment: record linkage study', British Medical Journal 317: 1283-1286.

Marsh, Ian (2010) Suicide: Foucault, History and Truth. Cambridge: Cambridge University Press.

Marshall, James R. (1981) 'Political Integration and the Effect of War on Suicide: United States, 1933-76', Social Forces 59(3): 771-785.

McGowan, Ian, Hamilton, Stephen, Miller, Paul and Kernohan, George (2005) 'Contrasting terrorist-related deaths with suicide trends over 34 years', Journal of Mental Health 14 (4): 399-405.

McKittrick, David, Kelters, Seamus, Feeney, Brian, and Thornton, Christopher (1999) Lost Lives: The Stories of the Men, Women and Children Who Died as a Result of the Northern Ireland Troubles. Edinburgh: Mainstream Publishing. 
Miller, Robert L., Devine, Paula and Schubotz, Dirk (2003) Secondary Analysis of the 1997 and 2001 Northern Ireland Health and Social Wellbeing Surveys. Belfast: Queen's University. http://www.dhsspsni.gov.uk/sws_secondary_analysis.pdf

Muldoon, Orla, Schmid, Katharina, Downes, Ciara, Kremer, John and Trew, Karen (2005) The Legacy of the Troubles: Experience of the Troubles, Mental Health and Social Attitudes. Belfast: School of Psychology, Queen's University.

National Advisory Committee on Drugs (NACD) and Drug and Alcohol Information and Research Unit (DAIRU) (2003) Drug Use in Ireland \& Northern Ireland, First Results from the 2002/2003 Drug Prevalence Survey, Bulletin 1, October. Dublin/Belfast.

Northern Ireland Registry of Deliberate Self-Harm (2010) Annual Report 2009. http://www.cawt.com/default.aspx?CATID=1183

Northern Ireland Statistics and Research Agency (various years) Continuous Household Survey. Belfast.

O'Connor, Rory C. and Sheehy, Noel, P. (1997) 'Suicide and Gender', Mortality 2(3): 239-254.

O’Malley, Patrick (1975) 'Suicide and War: A Case Study and Theoretical Appraisal', British Journal of Criminology 15(4): 348-359.

Padiak, Janet (2009) 'Death by Suicide in the British Army, 1830-1900', in J. Weaver and D. Wright (eds) Histories of Suicide: International Perspectives on Self-Destruction in the Modern World, pp. 119-134. Toronto: University of Toronto Press.

Payne, Douglas (1998) 'Male suicide rate rises as Irish Troubles ease', British Medical Journal 316 (7148): 1850.

Prestwich, Patricia E. (2009) 'Suicide and French Soldiers of the First World War: Differing Perspectives, 1914-1939', in J. Weaver and D. Wright (eds) Histories of Suicide: International Perspectives on Self-Destruction in the Modern World, pp. 135- 155. Toronto: University of Toronto Press.

Prior, Lindsay (1985) 'Making Sense of Mortality', Sociology of Health \& IIIness 7(2): 167-190. Registrar General Northern Ireland (1965-2010) Registrar General Northern Ireland Annual Reports (Forty-Fourth to Eighty-Eighth). Belfast: Stationery Office.

Sainsbury, Peter (1971) 'Suicide in London’, in A. Giddens (ed) The Sociology of Suicide. London: Frank Cass. pp. 246-258. 
Sainsbury, Peter and Jenkins, J. S. (1982) 'The accuracy of officially reported suicide statistics for purposes of epidemiological research', Journal of Epidemiology and Community Health 36: $43-48$

Selakovic-Bursic, Slavica, Haramic, Elisabeth, and Leenaars, Antoon A. (2006) 'The Balkan Piedmont: Male Suicide Rates Pre-war, Wartime, and Post-war in Serbia and Montenegro', Archives of Suicide Research 10: 225-238.

Shirlow, Peter and McEvoy, Kieran (2008) Beyond the Wire: Former Prisoners and Conflict Transformation in Northern Ireland. London: Pluto Press.

Smith, Lesley and Foxcroft, David (2009) Drinking in the UK: an exploration of trends. York: Joseph Rowntree Foundation.

Stuckler, David, Basu, Sanjay, Suhrcke, Marc, Coutts, Adam and McKee, Martin (2011) 'Effects of the 2008 recession on health: a first look at European data', The Lancet 378: 124-5.

Sutton, Malcolm (1994) Bear in Mind These Dead: An Index of Deaths from the Conflict in Ireland 1969-1993. Belfast: Beyond the Pale Publications.

Timmermans, Stefan (2005) 'Suicide Determination and the Professional Authority of Medical Examiners', American Sociological Review 70(2): 311-333.

Tomlinson, Michael W. (1995) 'Imprisoned Ireland' in V. Ruggiero, M. Ryan and J. Sim (eds) Western European Penal Systems: a critical anatomy, pp. 194-227. London: Sage.

Tomlinson, Michael W. (2006) The Trouble with Suicide: Mental Health, Suicide and the Northern Ireland Conflict: A Review of the Evidence. Belfast: Department of Health, Social Services and Public Safety (Northern Ireland).

Van Poppel, Frans and Day, Lincoln H. (1996) 'A Test of Durkheim's Theory of Suicide without committing the "ecological fallacy"', American Sociological Review 61: 500-507.

Van Tubergen, Frank and Ultee, Wout (2006) 'Political Integration, War and Suicide: The Dutch Paradox?', International Sociology 21(2): 221-236.

Wessely, Simon (2005) 'War stories: Invited commentary on documented combat exposure of US veterans seeking treatment for combat-related post-traumatic stress disorder', British Journal of Psychiatry 186: 473-475. 
Whitt, Hugh (1994) 'Old Theories Never Die' in N. P. Unnithan, L. Huff-Corzine, J. Corzine and H. P. Whitt (eds) The Currents of Lethal Violence: An Integrated Model of Suicide and Homicide, pp. 7-34. Albany: State University of New York Press. 